\title{
Rural-urban residence, modernism and fertility: a study of Mwanza region, Tanzania
}

\author{
George F. Masanja \\ St. Augustine University of Tanzania \\ Department of Geography \\ Tel: +255784447156 \\ E-mail: grgmasanja@yahoo.co.uk
}

\begin{abstract}
The aim of this study is to assess the effect of rural-urban residence and modernization on fertility preference among urban female migrants versus rural female non-migrants. The specific objective is to assess the impact of the amount and timing of urban residential experience on six dimensions of modernism in attitudes and behaviour. A sample of 397 women of the reproductive age living in Mwanza region was interviewed in 2012. Data were collected using structured questionnaires and focus group discussions. Data analysis technique employed was multivariate using SPSS version 16.0 and ethnograph softwares for quantitative and qualitative data respectively. Results show that scores on modernism indices were consistently higher for women with urban residential experience. Women who migrated from villages to the city reported attitudes and behaviours more modern than women with no urban residential experience. The study concludes that the change from traditional to modern values, norms and behaviours among female migrants came from gaining an urban experience. Thus recommending that women's migration empowerment is crucial to fertility regulation in Tanzania.
\end{abstract}

Keywords: Rural-urban, residence, modernization, fertility, duration

\section{Résumé}

Les données on résultats de la région de Mwanza, dans lesquelles 397 femmes de l'âge reproductif habitant dans les zones urbaines des secteurs d'lgoma et Mbugani et d'autres de Buhingo et Ukiriguru interviewées en 2012 sont utilisées pour étudier les effets des résidences urbain-rurales et la modernisation sur la préférence de la fertilité parmi les femmes immigrant vers les villes contre les femmes rurales qui restent sédentaires. Elles étudient aussi l'impact quantitatif et la durée de l'expérience de résidence urbaine sur six dimensions de modernité dans les attitudes et le comportement. Les résultats sur la modernité étaient constamment supérieurs pour les femmes qui ont une expérience de la vie urbaine comparé à ceux des femmes qui vivent dans les régions rurales. Cependant, quant aux femmes qui immigrant des villages vers les villes, elles ont montré des attitudes et comportements plus modernes que celles qui n'ont aucune expérience de vie urbaine. L'attitude de modernité contribue beaucoup à l'explication de comportement sur la fertilité et les préférences sur elle, indépendamment des variables de départ. Mais il ya peu d'évidence pour soutenir les théories que la modernité sert de tremplin intervenant entre les variables de départ et le comportement sur la fertilité on préférence sur elle.

Mots clés: L’Urbain-rurales, résidences, modernisation, fertilité, duration 


\section{Introduction}

Migration exerts both direct and indirect effects on urban population growth (Cohen, 2006; White, Mberu, and Collinson, 2008; Arif and Hamid, 2009). The direct contribution of migrants derives from the initial migration streams which set in motion secondary chain migration to the same destination. Indirectly, migrants contribute to urban population growth through their reproductive behaviour (Csata and Kiss, 2007). To the extent that a large proportion of urban in-migrants in Africa consists of young persons and mostly first generation migrants who invariably import to the cities their rural reproductive behaviour, thus urban fertility is likely to be boosted by migrants simply for this reason. In the long run, the process of adaptation (some argue selection) and modernization may ultimately reduce the fertility of migrants (Holmes, 1976).

While rural-urban fertility differentials have long been established for most developing societies, the causes and exact nature of these differences among the migrants and between migrants and those of succeeding generations is not well understood (White et al 2002; Muhidin and Ledent, 2005). For instance, some studies speculate that socio-cultural changes, or degree of modernization, can create conditions, which tend to increase fertility (Abbas, et al 2003; Al-Kandari, 2007). If this is so, there may be a positive relationship at the individual level between modernization and fertility. On the other hand, socio-cultural changes can create conditions, which tend to decrease fertility (Ceccato, 2000; Odile and Bongaarts, 2006, Natasha Courtenay-Smith and Morag Turner 2007,). If so, when individuals or populations are classified on a scale of modernization, an inverse relationship between modernization and fertility may be found. Thus, relationships differ not only in magnitude but also in direction, in different settings and at different times. Whatever the merits of these individual studies, they raise one important problem. The way in which rural-urban residence and modernization alter fertility outcomes is not widely known. This study, therefore, seeks to address this problem. The general objective of this study is to assess the effect of rural-urban residence and modernization on fertility behavior and preference among urban female migrants versus rural female non migrants. Specifically, the study seeks to determine the socioeconomic and demographic profiles of urban female migrants versus rural female non migrants; to determine their levels of modernism and their effect to fertility preference; and to assess the impact and timing of urban residential experience on six dimensions of modernism in attitudes and behavior.

\section{Literature review and theoretical frame- work}

Differentials in fertility behaviour and levels in different areas, and among population strata or characteristics, have been one of the most pervasive findings in demography (White et al, 2005; Brown-Guinnane, 2007). One major cause of the differentials is the association between the migration process and fertility behaviour or preference. Research has shown that women who migrate to new environments such as urban centres where education is high, jobs are available, and high living standards, show almost universally lower fertility than their counterparts in rural areas of low education standards, nonavailability of jobs or otherwise blue collar jobs, and low standards of living (Garenne and Joseph, 2002; Gugler, 2008).

With this light, this study takes into account of a theoretical framework which posits that there are three theories (Selection, Disruption, and Adaptation) which seek to explain how rural-urban migration can affect fertility either before, during, or after the move. Common to these theories are two assumptions: I) rural fertility levels exceed urban fertility levels, and 2) fertility levels of rural-urban migrants are lower than rural residents.

\section{The Selection Theory}

It suggests that migrants are a self-selected group who differ from non-migrants in the rural areas based on higher education attainment, later age at marriage, lower pre-migration fertility, and employment for wages (Haapanen 2003; Kulu 2005). As hypothesized, the impact of migration on fertility has its effect before the move, since the pre-migration characteristics believed to motivate migration are also associated with both lower pre- and postmigration fertility. Manner (2003) suggests that migrant selection is based on distinct preferences for family size, which are not predicted socioeconomic characteristics, and thus determine who migrates and to where. For example, women/families with small family-size ideals move to large urban areas.

\section{The Disruption Theory}

It posits that the act of migration interrupts fertility during the period of the move. This could be due to the physical separation of the spouses or a conscious decision to postpone childbearing (Lindstrom 
and Saucedo 2002; Kulu 2005). This disruptive effect curtails a woman's reproductive performance around the time of the move, and can lead to lower fertility among migrants relative to people who have never moved or it can lead to accelerated fertility in the post-migration period, called the "catch up" effect (Hervitz, 1985). The impact of the catch-up effect depends on the woman's age at migration, i.e. the amount of reproductive time left of fecundity during that period.

\section{The Adaptation Theory}

It has its roots both in the sociological and economic theories explaining the determinants of fertility (Findley 1980). From the sociological perspective, the adaptation theory posits that fertility is determined by social and cultural norms operating in the area of residence. For migrants moving between two types of areas, rural and urban, where presumably these norms differ, their fertility behaviour will reflect the combined influence from both areas (Chattopadhyay and White (2006); and Kulu (2005) describe the adaptation process primarily from an economic perspective, naming rural-urban differences in relative wages for men, women and children, and price and income constraints, as explanatory variables for fertility change due to urban migration. Exposure to different relative incomes and costs will lead to adaptation of different fertility behaviour, such that migrant fertility will ultimately converge to that of urban non-migrants. Kulu (2005), in particular, emphasizes the importance of housing. He argues that the size of living spaces is related to overall living and opportunity costs which impact fertility decisions. This part of adaptation theory supports the economic aspects of fertility decision-making as well as the evaluative aspect of social interaction theory. In either case it is the "duration of exposure" to urban norms, measured by length of residence, which determines the extent of fertility change due to migration.

Of course, these theories are not mutually exclusive. It is probable that all three hypothesized effects of migration on fertility operate to some extent during the migration process.

Basic to the understanding of the relationship between modernism and fertility is the effect of place of residence. Some studies have indicated the powerful effect of urban residence in accounting for lower fertility levels (Shapiro and Tambashe 2000; Tungu, 2005). Urban residence may occur in the early stages of a woman's life or at later times, and the length of exposure or living in an area may also be of critical consideration (Drèze and Murthi, 200I; Gugler, 2008).

Likewise, the issue of whether modernity functions as an intervening variable linking social status and fertility behavior has aroused interest among researchers. Social demographers in many countries have investigated the causes and consequences of fertility variations in relation to diverse socioeconomic and cultural segments. On studying individual modernity, Shastri, (2002) has taken variables such as education, exposure to mass media, urban residence, possession of consumer durables such as radio and camera, subjective efficacy, orientation towards time, willingness for new experience, openness to change etc, However, the objective of that study was to study modernization rather than linking modernization with fertility.

Studies have also indicated the powerful effect of urban residence in accounting for lower fertility levels. Urban residence may occur in the early stages of a woman's life or at later times, and the length of exposure or living in an area may also be of critical consideration (Goldstein and Goldstein, 1983).

Wasao (200I) using multivariate analysis found that urban residence and high level of education associated with lower fertility in Cameroon. In Mozambique also similar results found that modernization led to low fertility (Wasao, 200I)

Garenne and Joseph (2002) using data from DHS (Demographic Health Survey) and WFS (World Fertility Survey) in 30 sub Saharan Africa countries by using an innovation approach to investigate the cause of fertility decline indicates that in many countries, fertility started to decline in the late 1960s and 1970 s in urban areas, and about 10 years later in rural areas. This implies urbanization plays a major role in inducing fertility decline.

Shapiro and Gebreselassie (2008) using data from DHS to examine the status of fertility transition in sub-Saharan countries focused on the link between socioeconomic factors and fertility decline and stalling. They found an evidence of a significant negative association of education, infant and child mortality and GDP growth.

The theory of modernization and its impacts on family structure and function began basically in the 1950s and 1960s (Webster, 1990; Harrison, 1988). Related discussions and controversies in this period centered around notions suggested by many functionalists that modernization and industrialization led to a shift from a predominantly extended to a predominantly nuclear family structure and that this shift arguably weakens the traditional functions of 
the family in general (Parsons \& Bales, 1955). However, most studies have tended to focus on processes of industrialization and urbanization while other central features, including particular cultural and economic conditions, have often been deliberately ignored.

The gap emerging from the existing literature which this study tries to fill is the underreported transformation process entailed in individuals perceptions and attitudes towards family size limitation being a consequence of the interaction between structural changes and fertility decline which has been a historical experience in developed countries and not in developing countries, particularly in African countries during societal modernization.

\section{Data and methods}

The study was undertaken in Nyamagana and Misungwi Districts of Mwanza region, Tanzania. For reasons of comparability and assessment, the former district is entirely urban and the latter is mainly rural. The study covered female respondents of the reproductive age group 15-49 years and those who have completed parity. The time span covered by the study was from 1986 to 2012 . This time period is sufficient enough to capture assessment of crosssectional reproductive behavioural changes for both rural-urban female migrants and rural female non migrants.

To assess the influence of rural-urban residence of females on fertility levels, this study adopted a combination of two research approaches mainly cross-sectional and causal-comparative suitable for a study intending to make a comparative assessment between female urban migrants as a treatment group and rural female non-migrants as a control group on the assumptions that female urban migrants exposed to modernization tend to show lower levels of fertility than their counterparts and also that rural and urban environments lead to differential fertility despite similar modernity levels.

The study design utilized a constructed modernity index which took into consideration of the following modernization variables: Mass Media exposure- watching TV, listening to radio, going to video hall to see a movie, reading newspapers, and reading books. Nuclear family role structure - decision making and responsibilities of women. Extended family ties obligations of children to provide monetary and material support to parents and expectation of old age support from children. Religiosity - intensity of religious involvement. House wares - sofa set, sewing machine, radio/TV, refridgerator and clock. Outhouse possessions- bicycle, motor bicycle, car, bullock cart, water pump and tractor.

For each of these variables, a question was asked and scores were allotted.

The modernization variables tested were grouped into six homogeneous categories and each one produced an index. If a respondent owned any one of these, the score was I. If another respondent owned all the items in a particular sub modernity group, the score given was equivalent to the maximum number of items found in that sub modernity group. The classification of less modern and more modern in rural and urban samples was based on the scores achieved. The highest score was given to the highest modernity achievement, and the lowest score was given to the lowest modernity achievement and based on these scores, sampled wards were divided into "less and more modern" to ease comparison.

The population for the study was drawn from randomly sampled wards of Nyamagana and Misungwi Districts of Mwanza region. Two wards were picked from each district. lgogo and Mbugani were chosen for Nyamagana District while Buhingo and Ukiriguru were taken from Misungwi District. Based on population data from the national census of 2002, a sampling frame comprising all female urban migrants aged 15 years to 49 residing in lgogo and Mbugani wards of Nyamagana District and rural female non migrants currently residing in Buhingo and Ukiriguru Wards of Misungwi District was used to draw up a sample. Statistics of eligible females per age group in these areas were projected to the year 2012. 
Table I Projected Female Population of reproductive age by District and Study ward

\begin{tabular}{|c|c|c|c|c|c|}
\hline \multirow{3}{*}{$\begin{array}{l}\text { Name } \\
\text { of District/Ward }\end{array}$} & \multicolumn{5}{|c|}{2002 Female population of reproductive 2012 Projected female } \\
\hline & \multirow[b]{2}{*}{ Age group } & \multicolumn{4}{|c|}{ Population of reproductive age } \\
\hline & & lgogo & Mbugani & lgogo & Mbugani \\
\hline \multirow[t]{8}{*}{ Nyamagana } & $15-19$ & 1676 & 2315 & 4634 & 6401 \\
\hline & $20-24$ & 1994 & 2706 & 5513 & 7482 \\
\hline & $25-29$ & 1519 & 2158 & 4200 & 5967 \\
\hline & $30-34$ & 966 & 1366 & 2671 & 3777 \\
\hline & $35-39$ & 612 & 825 & 1692 & 2281 \\
\hline & $40-44$ & 509 & 592 & 1407 & 1637 \\
\hline & $45-49$ & 286 & 356 & 791 & 984 \\
\hline & Total & 7562 & 10318 & 20908 & 28529 \\
\hline \multirow[t]{8}{*}{ Misungwi } & Age group & Buhingo & Ukiriguru & Buhingo & Ukiriguru \\
\hline & $15-19$ & 551 & 421 & 735 & 562 \\
\hline & $20-24$ & 408 & 371 & 544 & 495 \\
\hline & $30-34$ & 318 & 267 & 424 & 356 \\
\hline & $35-39$ & 233 & 178 & 311 & 237 \\
\hline & $40-44$ & 226 & 145 & 301 & 193 \\
\hline & $45-49$ & 115 & 113 & 153 & $15 \mid$ \\
\hline & Total & 2262 & 1847 & 3016 & 2463 \\
\hline
\end{tabular}

Source: NBS 2002 Tanzania Population and Housing Census

The total population for the study is $\mathbf{5 4 , 9 1 6}$

The method of exponential extrapolation was used. From the population outlined above, a sample size of 397 respondents was determined using the Yamane (1967) formula.

$$
n=\frac{N}{1+N(e)^{2}}
$$

Where $\mathrm{n}$ is the sample size, $\mathrm{N}$ is the population size, and e is the level of precision ( $\pm 5 \%$ ) which was desired. For Focus Group Discussions (FGDs), audience segmentation was employed to comply with established selection criteria for eligibility.

Two main methods of data collection were used. These were namely; a structured questionnaire and FGDs. For audience research, 4 FGDs each consisting of 10 participants each were conducted. A total of 40 participants were involved in FGDs. There were 2 FGD in each district. One was for female urban migrants and another for non-migrants. Each FGD embraced homogeneity with respect to varia- bles such as age, education, marital status, and economic status. Participants were drawn from a convenient locale and were selected from among the respondents. Lastly, latest and relevant statistical publications from the National Bureau of Statistics (NBS), mainly Tanzania Demographic Health Surveys (TDHS) of 2004 and 2010 were also consulted.

The data from TDHS showed that the total fertility rate in Tanzania is 5.4 births per woman. The Total Fertility Rate (TFR) among rural women on the Mainland (6.I births) is higher than among urban women (3.7 births). At all ages, age specific fertility rates are substantially higher for rural than for urban women. The greatest absolute difference in agespecific fertility rates between urban and rural women in Mainland occurs at age 20-24 (106 births per I,000 women) (NBS and ICF Macro, (20I0).

The sample was then broken down to respective study wards using the formula shown below. The 
distribution of prospective respondents is also shown in Table 2 below.

$$
\mathrm{Sn}=\frac{\mathrm{T}}{\mathrm{N}} \times \mathrm{S}
$$

Where: $\mathrm{Sn}=$ Calculated sample of the ward.

$\mathrm{N}=$ Number of females of the reproductive age in the ward.
$\mathrm{T}=$ Total females of the reproductive age in the selected wards.

$\mathrm{S}=$ Sample size

Calculation of a sample for Buhingo for example was done as follows:

$$
\mathrm{Sn}=\frac{\mathrm{N}}{\mathrm{T}} \times \mathrm{S}=\frac{3016}{54,916} \times 397=22
$$

\begin{tabular}{|c|c|c|c|}
\hline \multicolumn{2}{|c|}{ Selected Districts/wards } & Projected populations (20I2) & Calculated sample sizes \\
\hline \multirow[t]{2}{*}{ Misungwi } & Buhingo & 3016 & 22 \\
\hline & Ukiriguru & 2463 & 18 \\
\hline \multirow[t]{2}{*}{ Nyamagana } & Igogo & 20908 & $12 \mid$ \\
\hline & Mbugani & 28529 & 206 \\
\hline Total & & 54916 & 397 \\
\hline
\end{tabular}

Table 2 Distribution of selected wards with their population and sample sizes

Source: Nyamagana and Misungwi Modernism and Fertility Survey, 2012

Analysis for both quantitative and qualitative data was done. As to the former, descriptive statistical procedures including cross tabulations and frequency distributions were used to provide comparisons and contrasts between urban female migrants and rural female non migrants. Secondly inferential statistical analysis, namely chi-square and correlation tests were used to establish associations or relations among variables investigated.

All the socioeconomic background variables i.e. residence, religion, education, occupation, demographic variables (age at marriage, number of children ever born, children living) and attitudinal variables (husband and wife communication about family size preference, desired ideal family size, expected family size and ideal family size were analysed by modernity index as well as status of fertility (completed or uncompleted). Chi-square tests were applied to determine significance of their associationships.

Analysis of levels of modernism among female urban migrants versus rural female non migrants was performed through cross tabulation of more modern and less modern categories of respondents by background variables and status of fertility. This was followed by an application of Multiple Classification Analysis (Andrew, Morgan, and Sonquist, 1967) as a measure of the relationship between variances among modernism indices and residential classifications.

Analysis of the impact of the amount and timing of urban residential experience on the six dimensions of modernism in attitudes and fertility behaviour was done by associating them with modernity and fertility. These were analyzed through correlations.

Analysis of the relationship between modernization and fertility behaviour among urban female migrants versus rural female non migrants was done by subjecting selected background variables to modernity index with a view to study the relationship between the level of modernity and fertility preference. Zero-order and partial correlations were applied to establish the strengths of associations.

As regards qualitative data analysis, tapped focus group discussions were transcribed verbatim and with the help of questions or themes in the FGD guide, main themes or patterns obtained from narrative data were identified and these themes were arranged into coherent categories. A descriptive label (name) to each theme was provided for each category created. Similarities and differences as well as relationships in participants' responses in each category were captured and summarized.

The timing or duration of residence as a measure for the effects of residence on modernism in Mwanza City was measured by dividing the respondents' 
life cycles into five periods: (i) birth, (ii) between birth and age seven (a period in which access to education begins), (iii) between age eight and the time of marriage or procreation (a period in which socialization into adult roles becomes more intense), (iv) between marriage or procreation and interview and $(v)$ the time of interview.

The type of community in which the respondent lived in each of the five life cycle stages was determined. The study schedule only included the current residence, longest previous residence, place of birth, and timing of migration to the urban area. The study assumed that the respondents lived in their previous residence continuously, from birth to the time of migration to Mwanza City. Using this assumption and the respondents' age at migration, the place of longest residence in each life cycle period was determined. If they moved on or after the midpoint of a life cycle period, their place of longest residence in that and all earlier periods was assumed to be her residence prior to migration. If they moved to the urban area prior to the middle of the period, then their current residence was assumed to be their place of longest residence during this life cycle period.

\section{Results}

The total number of women studied were 397 comprising 40 from Misungwi District and 357 from Nyamagana District. Women with uncompleted fertility were 27 and 294 for Misungwi and Nyamagana respectively. Of the total respondents with uncompleted fertility in Misungwi District, 59\% belonged to Buhingo and $41 \%$ from Ukiriguru, while in Nyamagana District, a higher percentage (63) \% was from Mbugani. Through bifurcation of rural and urban sample into less modern and more modern by adapting the methodology explained, Misungwi carved out more of less modern (81.48\%) than Nyamagana $(78.23 \%)$ urban sample. In respect of the completed fertility sample, the rural sample of Misungwi District had a major proportion of (69.23\%) under the less modern category as compared to the urban sample of Nyamagana District which accounted for $61.9 \%$

Table 3 Distribution of Incomplete Fertility Women by degree of Modernity in Misungwi and Nyamagana Districts

\begin{tabular}{|c|c|c|c|c|c|c|c|c|c|}
\hline \multicolumn{4}{|c|}{ Misungwi District } & \multicolumn{6}{|c|}{ Nyamagana District } \\
\hline Study Wards & $\begin{array}{l}\text { Less Modern } \\
\text { (I) }\end{array}$ & $\begin{array}{l}\text { More Modern } \\
\text { (2) }\end{array}$ & $\begin{array}{l}\text { Total } \\
3(I+2)\end{array}$ & Study Wards & $\begin{array}{c}\text { Less Modern } \\
\text { (4) }\end{array}$ & More $\mathrm{M}$ & $\begin{array}{l}\text { dern } \\
\text { 5) }\end{array}$ & & $\begin{array}{l}\text { l1 } \\
+5)\end{array}$ \\
\hline Buhingo & $13(48.14)$ & $3(\mathrm{II} .1 \mathrm{I})$ & $16(59.25)$ & lgogo & $89(30.27)$ & 196 & & 108 & 5.73) \\
\hline Ukiriguru & $9(33.33$ & $2(7.4)$ & II (40.74) & Mbugani & I4I (47.95) & $45(1$ & 30) & $186(C$ & 3.26) \\
\hline $\begin{array}{l}\text { Total } \\
(100) \\
\end{array}$ & $22(81.48)$ & $5(18.52)$ & $27(100)$ & Total & 230 & (78.23) & 64( & (1.76) & 294 \\
\hline Grand Total & 321 & & & & & & & & \\
\hline
\end{tabular}

Note: Figures in the parentheses indicate percentages of the total

Source: Nyamagana and Misungwi Modernism and Fertility Survey, 2012

\section{Marital status of Respondents}

Data from the survey shows that in Misungwi District about 4 (10\%) of all respondents were widowed, 3 women $(7.5 \%)$ were co-habiting, 7 women (17.5\%) were married, 14 women $(35 \%)$ were single, 9 women $(22.5 \%)$ were divorced, and 3 (7.5\%) were separated. For Nyamagana District, 8 women $(2.2 \%)$ were widowed while 16 women (4.5\%) were cohabiting. About 134 women (37.5\%) were married, 121 women (33.9\%) were single and 32 women $(9.0 \%)$ were already divorced. Those who were separated were 46 constituting $12.9 \%$ ).

\section{Respondents Marital Status and age}

I4I respondents in both districts (about 35.5\% of all respondents) were married. Of these, $17.6 \%$ were in the age group of 35-54 years (Middle age group). About $15.3 \%$ were in the age group of 15 34 years (young age group). A total of 19 respondents, about $4.8 \%$ of all respondents were cohabiting. The majority of them, about $3.2 \%$ belonged to the age group of $15-34$ years. 12 respondents (about $3 \%$ of all respondents) were widowed and a majority of them $2 \%$ belonged to the age group of 55 and above (old age group). 49 respondents ( $12.4 \%$ of total respondents) were separated, of which $4(8.2 \%)$ were in the age group of 55 . An- 
other $4 \mathrm{I}$ respondents ( $10.3 \%$ of total respondents) were divorced.

Data from the Focus group discussion (FGD) indicated an increasing number of female widows who are refusing to remarry, because they think that they would be compelled to continue giving birth to new babies. If they simply take care of those whom they have already given birth, there is no need for them to re-marry.

\section{Religion and Modernity}

In both districts, it was observed from the religion-wise distribution that, the majority $(42.9 \%)$ in all the segments were traditional believers, followed by Catholics (35.4\%), Muslims accounted for (13.6\%). All other religions combined constituted (8.1\%). While in Misungwi rural district, traditional believers were more than those in urban Nyamagana $(45.4 \%$ by $40.4 \%$ respectively), the proportions of Catholics and Muslims in the urban sample (Nyamagana) were more than those in rural Misungwi $\left(52.8 \%\right.$ by $45.2 \%$ respectively). $X^{2}$ values were significant for the urban sample indicating that religion has a bearing on the modernity outlook of this group, while it was not so for the rural sample. A chi-square computation showed a result of 46 against a table value of $32.67 \mathrm{I}$ for $2 \mathrm{I}$ degrees of freedom at the 5 percent level of significance. This result shows that the calculated value was greater than the table value indicating that religion and modernity were statistically associated.

\section{Education and Modernity}

In Misungwi District, 10\% of the respondents with uncompleted fertility had primary education while $5 \%, 4 \%, 2 \%, 3 \%$ and $3 \%$ had secondary education, technical education (vocational training), adult education, no formal education and other type of education (like madrasa) respectively. For Nyamagana District, $40.5 \%$ with uncompleted fertility had primary education while $33.7 \%, 15.5 \%$, $5.4 \%, 1.0 \%$ and $4.1 \%$ had secondary education, technical education (vocational training), adult education, no formal education and other type of education respectively. Comparison between female respondents with completed fertility in both districts shows that Nyamagana District had higher figures in all levels of education. Generally, the study showed that the majority of the respondents had primary education. These results could be due to the implementation of the Universal Primary Education (UPE) of the 1970s, which provided educational opportunity to all children with appropriate age all over the country. Chi-square calculations for data showed a result of 51.6 against a table value of 49.7655 for 35 degrees of freedom at the 5 percent level of significance. This result shows that the calculated value was greater than the table value indicating that Education and modernity were statistically associated.

\section{Occupation and Modernity}

An assessment was made on occupations for both urban female migrants and rural non migrants by asking them to state their occupations. The highest proportion of female respondents in Misungwi was farmers (48.1 \% for uncompleted fertility group and $46.2 \%$ for those with completed fertility), followed by those who had no specific work to perform (14.8\%). Most of these are dependants and they are either school girls or are under the custody of their parents or guardians. The employed, formed the minority (11.1\% for the incomplete fertility group and $7.7 \%$ of the completed fertility group) and most of these are government workers mainly teachers and health workers. In the case of Nyamagana District, business women formed the majority $(55.1 \%)$ for the uncompleted fertility group and $34.9 \%$ for the completed fertility group followed by the employed group ( $16.7 \%$ and $27 \%$ respectively). The calculated $X^{2}$ value of the data yielded a value of 98.8. Since this value is higher than the table value 21.026 for 12 degrees of freedom at $5 \%$ level of significance, then the difference is significant. Data from the FGD indicated an increasing number of females who are becoming self dependent in terms of economic activities.

\section{Levels of modernism among urban and rural women}

An attempt was made to establish whether residence had an effect on modernism. For comparison purposes, levels of modernism among women living in an urban community and those living in a rural environment were determined. Results presented in Table 4 clearly indicate that such differentials do exist in the study population. 
Table 4 Mean Modernism scores on six indices of Modernism by current and previous places of Residence for a sample of Misungwi and Nyamagana Districts

\begin{tabular}{|c|c|c|c|c|c|c|}
\hline Place of residence & $\begin{array}{l}\text { Mass } \\
\text { Media }\end{array}$ & $\begin{array}{l}\text { Extended } \\
\text { family } \\
\text { ties }\end{array}$ & $\begin{array}{l}\text { Nuclear } \\
\text { family } \\
\text { ties }\end{array}$ & Religiosity & $\begin{array}{l}\text { In house } \\
\text { possessions }\end{array}$ & $\begin{array}{l}\text { Out house } \\
\text { possessions }\end{array}$ \\
\hline \multicolumn{7}{|l|}{ Current residence } \\
\hline - Nyamagana & 3.31 & 3.17 & 3.20 & 3.11 & 3.32 & 3.27 \\
\hline - Misungwi & 2.30 & 2.53 & 2.36 & 2.60 & 2.29 & 2.24 \\
\hline$\circ$ Accessible & 2.01 & 2.31 & 2.22 & 2.66 & 2.51 & 2.12 \\
\hline ○ Inaccessible & 3.35 & 3.20 & 3.30 & 3.32 & 3.20 & 3.23 \\
\hline \multicolumn{7}{|l|}{ Previous Residences } \\
\hline \multicolumn{7}{|c|}{ - Longest post-marital residence } \\
\hline - Nyamagana & 4.19 & 3.48 & 4.02 & 4.10 & 3.57 & 3.78 \\
\hline ○ Misungwi & 3.58 & 3.30 & 3.61 & 3.12 & 3.21 & 3.48 \\
\hline \multicolumn{7}{|c|}{$\begin{array}{l}\text { - Longest residence; Age } 7 \text { to mar- } \\
\text { riage }\end{array}$} \\
\hline ○ Nyamagana & 3.24 & 2.91 & 3.22 & 3.02 & 2.96 & 3.12 \\
\hline ○ Misungwi & 2.22 & 2.31 & 2.70 & 2.65 & 2.65 & 2.28 \\
\hline \multicolumn{7}{|c|}{ - Longest residence: Birth to age 7} \\
\hline o Nyamagana & 3.73 & 3.29 & 3.51 & 3.46 & 3.46 & 3.42 \\
\hline ○ Misungwi & 4.22 & 3.42 & 4.01 & 4.01 & 4.01 & 3.74 \\
\hline \multicolumn{7}{|l|}{ - Birth places } \\
\hline ○ Nyamagana & 3.73 & 3.37 & 3.54 & 3.14 & 3.14 & 3.41 \\
\hline ○ Misungwi & 3.22 & 3.02 & 3.23 & 3.04 & 3.04 & 3.14 \\
\hline
\end{tabular}

Note: Scores standardized using a $(z+3)$ transformation.

Source: Nyamagana and Misungwi Modernism and Fertility Survey, 2012

Women currently living in Nyamagana (Mwanza City) consistently exhibited higher scores on the six dimensions of modernism than Misungwi rural women do. When women in Nyamagana were classified by their life cycle, the highest modernism scores are observed for Nyamagana urbanites (those born in the city). The scores for migrant females are somewhat lower and lowest are the scores for village women. The degree to which differences by place of residence appears varies considerably from one modernism index to another. For example women currently living in Nyamagana are sharply differentiated from women currently living in Misungwi villages on the Media exposure and In-house and Out-house possessions indices.

The percentage of variance in each modernisation index "explained" by each residential classification was calculated. These measures of relationship are based on the results of a Multiple Classification Analysis. For each modernism index, the measure given is the total sum of squares between community types divided by the total sum of squares (between all individuals in the sample) and multiplied by 100. Results suggest that birthplace is a more important explanatory factor than others such as longest post-marital residence. The urbanism factor, or residential history, has its strongest influence on the media exposure, nuclear family role structure, and in-house/out-house possessions index on modernism. The same factor exhibited a weaker influence with respect to extended family ties. The extreme low levels of explanation for the extended family ties measure with each of the residential classifications suggest a consequence of insufficient or inadequate data for the establishment of valid generalizations about the effects of extended family relations. No more than 9 percent of the variance in modernism scores on this index is accounted for by any one residential classification. In contrast, birthplace accounts for about half the variance in scores on the mass media index and a third of the variance in scores on the nuclear family role structure index. Current residence accounts for a quarter of the variance in scores on the in-house and out-house wares index.

\section{Effect of Timing of Migration upon Modernism}

The effect of timing of migration to Nyamagana upon modernism was also assessed. Here, the community of origin was held constant while the timing of migration is varied. Mean modernism scores (city score minus village score) were computed for those who migrated to Mwanza city dur- 
ing their adolescence or before being married against those who stayed in a rural environment since they were born. Results present a magnitude of differences showing that those females who moved immediately before marriage from the rural environment to Nyamagana were more modern since they have spent more of their life in an urban environment than those who moved after marriage. Conversely, those who migrated from the rural environment to Nyamagana at a later life cycle period (after marriage) were found to be less modern. Continued rural residence is an indicator of low modernity. Keeping these classification considerations in mind, it was found that the timing of migration has a greater impact on modernism.

\section{Fertility Preference}

Three dependent variables were used as indicators of the respondent's preferences of fertility. They are ideal family size (IFS), expected family size (EFS) and desired family size (DFS). An important aspect of fertility preferences has been its positive correlation with respondent's age. In the present study, age is used as a control variable. Using the average of family size preference as a cut off (2.9) the respondents were divided into two age groups: the below 34 group $(<34)$ and the 34 and over group $(\geq 34)$. The three indicators of fertility pref- erence were found to correlate more strongly with modernity than with the selected background variables, with one exception: expected family size has stronger correlation with respondent's education than with modernity for respondent's age 30 and over.

\section{The relationship between Modernity and Fertility}

Two types of analyses were applied in order to untangle the complicated interaction between modernity, background variables and fertility preference. First, zero - order correlations are presented to obtain information about strengths of relationships. Secondly, partial correlations between background variables and fertility preference, controlling for modernity, and between modernity and fertility preference, controlling for social status are presented.

\section{Zero order Correlations}

The findings from the zero-order correlations between indicators of background variables, modernity and fertility preferences show that all the correlations are in the predicted direction and nearly all are statistically significant. Table 5 presents the results.

Table 5 Zero-order Correlation Matrix by Age

\begin{tabular}{|c|c|c|c|c|c|c|}
\hline & Modernity & Respondent's Education & Place of Residence & IFS & EFS & DFS \\
\hline \multicolumn{7}{|l|}{ Age $<34$} \\
\hline Modernity & 1.00 & $.32 * *$ & $.13 * *$ & $-.28 * *$ & $-.27 * *$ & $-.27 * *$ \\
\hline Respondent's Education & & 1.00 & $.15 *$ & $-.17 * *$ & $-.23 * *$ & $-.22 * *$ \\
\hline Place of Residence & & & 1.00 & $-.10 * *$ & $-.17 * *$ & $.16 * *$ \\
\hline IFS & & & & 1.00 & $-.10 * *$ & $-.21 * *$ \\
\hline EFS & & & & & 1.00 & $-.21 * *$ \\
\hline DFS & & & & & & 1.00 \\
\hline \multicolumn{7}{|l|}{ Age $\geq 34$} \\
\hline Modernity & 1.00 & $.51 * *$ & $.22 * *$ & $-.34 * *$ & $-.15 * *$ & $-.33 * *$ \\
\hline Respondent's Education & & 1.00 & $.43 * *$ & $-.21^{* * *}$ & $-.3 I^{* * *}$ & $-.16 * *$ \\
\hline Place of Residence & & & 1.00 & $-.19 * *$ & $-.15^{* *}$ & $-.14 * *$ \\
\hline IFS & & & & 1.00 & $-.08 * *$ & $-.10 * *$ \\
\hline EFS & & & & & 1.00 & $.14 * *$ \\
\hline DFS & & & & & & 1.00 \\
\hline
\end{tabular}

\footnotetext{
$* P \leq .05$
}

$* * \mathrm{P} \leq .01$

Source: Nyamagana and Misungwi Modernism and Fertility Survey, 2012

The three indicators of fertility preference correlate more strongly with modernity than with the selected background variables, with one exception: expected family size has a stronger correlation with respondent's education than with modernity for respondent's age 30 and over. 


\section{Partial Correlations}

Partial Correlations are used to examine the relationship between fertility preferences and modernity. Most of the partial correlations between moder- nity and fertility preferences controlling for background variables are significant for both age groups. Table 6 presents the results.

Table 6. Partial Correlations between Modernity, Background Variables and Fertility Preferences by Age Cohort

\begin{tabular}{|c|c|c|c|}
\hline \multirow[t]{2}{*}{ Independent and Control Variables } & \multicolumn{3}{|c|}{ Fertility Preferences } \\
\hline & IFS & EFS & DFS \\
\hline \multicolumn{4}{|c|}{ Modernity Controlling For Respondent's Education and Place of residence } \\
\hline Age less than 34 & $-.21 * *$ & $-.16 * *$ & $-.15 * *$ \\
\hline Age 34 and over & $-.18 * *$ & -.04 & $-14 * *$ \\
\hline \multicolumn{4}{|c|}{ Background Variables Controlling For Modernity } \\
\hline \multicolumn{4}{|l|}{ Respondent's Education } \\
\hline Age less than 34 & -.04 & $-.15 * *$ & $-.13 * *$ \\
\hline Age 34 and over & $-1.15 * *$ & $-.22 * *$ & -.03 \\
\hline \multicolumn{4}{|l|}{ Place of Residence } \\
\hline Age less than 34 & -.06 & -.07 & -.06 \\
\hline Age 34 and over & -.05* & $-.11 *$ & -.03 \\
\hline
\end{tabular}

$* \mathrm{P} \leq .05$

$* * P \leq .01$

Source: Nyamagana and Misungwi Modernism and Fertility Survey, 2012

Four of the six partial correlations between fertility preferences and respondent's education controlling for modernity are significant. This implies that respondent's education contributes to the explanation of fertility preferences independent of modernity. Likewise, four of the six partial correlations between place of residence and fertility are significant.

\section{Discussion}

From the findings, it is clear that modern values and attitudes of Mwanza women contribute significantly to the prediction of fertility preferences. These psychological traits are primarily influenced by respondent's educational attainment followed closely by respondent's residence. The effects of modernism from background variables are such that most of the background variables pass through the index of modernism on their way to fertility behaviour or preferences. The intervening function of modern variables between background variables and fertility indicators suggested in the literature has varying effects. The results seem to indicate that both background variables and modernity variables work directly to inhibit fertility, with the bulk of the direct effect coming from respondent's education and modern values. Modernity, however, surpasses education in its influence on the fertility preferences of the respondent's younger than 34 whereas modernity and education share the effect for the respondents 34 years and above. Younger women tend to adopt modern attitudes in their decisions affecting child bearing more readily than older women for whom a joint effect of education and modernity may be necessary to bring about changes in fertility aspirations. These findings corroborate those reported by White et al 2002, Tungu 2005, and Bah, 2006.

\section{Conclusion}

This study had set out to examine three objectives. Conclusions are based on these objectives. Modernism indices were found to be consistently higher for urban female migrants than for rural female non migrants. This assertion emanates from the results which indicate that those migrating to cities such as Mwanza show a markedly lower level of modernism than the two generations urbanites. Again those who had migrated earlier to an urban centre such as Mwanza City showed a higher level of modernism 
than rural non migrant females. The reinforcement necessary to change from traditional to modern values, norms and behaviour among urban female migrants came from gaining an urban experience.

An assessment of the impact and timing of urban residential experience on six dimensions of modernism in attitudes and behavior showed that it is the longer life cycle residential experience that is the strongest determinant of modernism. Secondly, there is some small increment to modernism that accrues with urban experience. Further, the degree to which urbanism leads to modernism varies considerably according to specific dimensions of modernism. Owning in-house possessions has greater influence in suppressing fertility than that of out-house possessions. As regards the relationship between modernization and fertility behaviour and preference among urban female migrants in comparison to rural female non migrants, background variables and modern attitudes work directly to inhibit fertility with the bulk of the direct effect coming from respondent's education and modern values. Modernity however, surpasses education in its influence on fertility preferences of younger respondents. That is why there is a strong inverse relationship between modernization and fertility in respect of uncompleted fertility. Further, younger women tend to adopt modern attitudes in their decisions affecting childbearing more readily than older women. Younger urban female migrants, having acquired modern attitudes, norms and values tend to exhibit both lower fertility and fertility preference.

Overall, the Misungwi and Nyamagana case study of Mwanza Region has illustrated that what one believes and perceives, or the attitudes one holds will eventually be manifested in preferences and in action. Migration, modernity coupled with background variables is instrumental in fertility reduction. Urban migrants have significantly lower fertility than rural natives. The study suggests that women's access to education and decision making rights (empowerment) is crucial to fertility regulation in Tanzania. The policy implication of this result is to increase female empowerment by taking deliberate steps and interventions that support females in the migration process as well as in decision making regarding family size preferences. This study calls for more researches on western formulated modernity theories and their impacts on fertility in developing countries and Africa in particular.

\section{Acknowledgements}

The author extends sincere thanks to St. Augustine University of Tanzania management for providing the financial support for carrying out the research. I also thank anonymous reviewers for providing helpful comments to improve this article.

\section{References}

Abbasi-Shavazi, M.J., McDonald, P. HosseiniChavoshi M., (2003), Changes in family, fertility behaviour and attitudes in Iran, Working Papers in Demography, No. 88, Australian National University, Canberra.

Al-Kandari, Y. (2007). Fertility and its relationship with socio-cultural factors inKuwait society; Eastern Mediterranean Health Journal, Vol. 13, No 6, pp I365-1370.

Andrews, F., J. Morgan, and J. Sonquist (1967) Multiple Classification Analysis: A report on a computer programme for Multiple Regression usingCategorical Predictors. Ann Arbor: Survey Research Centre, Institute forSocial Research.

Arif, G and S. Hamid (2009). Urbanization, City Growth and Quality of Life inPakistan European Journal of Social Sciences - Volume 10, Number 2 pp 196-2/4

Bah, M. and al, 2006. 'Changing rural-urban linkages in Mali, Nigeria and Tanzania', in C. Tacoli (ed).The Earthscan Reader in rural-urban linkages. London, IIED.

Brown, J.C. and Guinnane, T. W. (2007). Regions and time in the European fertility transition problems in the Princeton Projects's statistical methodology, Economic History Review, vol. 60, number 3, pp 574-595

Ceccato V. A. (2000). Assessing the impact of modernization on fertility: The case of Mozambique. Austria: International Institute for Applied Systems Analysis, pp I- I5.

Chattopadhyay, A., White, M., and Debpuur, C. (2006). Migrant fertility in Ghana: Selection versus adaptation and disruption as causal mechanisms. Population Studies 60(2): 189-203.

Csata I. and Kiss T. (2007). Population perspectives Demographic and discursive analysis (Népesedési perspektívák - Demográfiai és diskurzív elemzés) Kriterion, 2007, Kolozsvár

Cohen, B. (2006). Urbanization in developing countries: Current trends, future projections, and key challenges for sustainability. Technology in Society 28: 63-80. 
Findley, S. (1980). Planning for internal migration. Washington: U.S. Bureau of the Census.

Garenne, M and V. Joseph (2002). The Timing of the Fertility Transition in Sub-Saharan Africa.World Development, vol. 30(10), pp. 1835-1843.

Goldstein, S. and A. Goldstein. 1983. Migration and Fertility in Peninsular Malaysia: an Analysis Using Life History Data, Rand Corporation Note, NI860-AID.

Gugler, J. (2008). Women stay on the farm no more: Changing patterns of rural-urban migration in Sub-Saharan Africa. Journal of Modern African Studies 27(2): 347-352.

Haapanen, M. (2003). Labour migration and wages; Licentiate Thesis, University of Jyväskylä, 82 p.

Harrison, D. (1988). The Sociology of Modernization and Development. London: Uniwin Hyman.

Hervitz, H. (1985). Selectivity, adaptation or disruption? A comparison of alternative hypotheses on the effects of migration on fertility: The case of Brazil. International Migration Review 19(2): 293317.

Holmes, D. L. (1976). "Migration and Fertility," in The Dynamics of Migration: Internal migration and migration and fertility. IWashington,D.C.: Interdisciplinary Communications Program, Smithsonian Occasional Monograph Series 5(2).

Jean Drèze \& Mamta Murthi, (200I). "Fertility, Education, and Development:

Evidence from India" Population and Development Review The Population Council, Inc., vol. 27(I), pp 33-63.

Kulu, H. (2005). "Migration and Fertility: Competing Hypotheses Re-examined." European Journal of Population 21: 5I-87.

Lindstrom, D. P. and S. G. Suacedo. (2002). "The short- and long-term effects of US migration experience on Mexican women's fertility. Social Forces 80(4): | $34|-| 368$.

Manner, C. K. (2003). A model of rural-urban migration and fertility: The journal of Developing Areas Vol 37 (I)

Muhidin, S. and Ledent, J. (2005). Migration and fertility in Burkina Faso: Evidence from the 2000 survey on migration, urbanization and environment. Paper presented at the the IUSSP XXV International Population Conference, Tours, France, July 18-23, 2005.

Natasha Courtenay-Smith, and Morag Turner (2007), "Meet the Women Who Won't Have Babies-Because They're Not Eco Friendly," Daily Mail, November 21
NBS and ICF Macro, (20I0). Tanzania Demographic and Health Survey Preliminary Report, National Bureau of Statistics, Dar es Salaam and ICF Macro Claverton, Maryland USA. p 46

Odile, F and J. Bongaarts (2006). Behavioural and biological determinants of fertility transition in sub-saharan Africa. Statistics in Medicine. Vol. Issue 2, pp I6I-I75

Parsons, T. \& Bales, R. F. (Eds.). (1955). Family, Socialization and Interaction

Process. New York: The Free Press.

Shapiro, D.,and B.O.Tambashe. 2000. "Fertility transition in urban and rural areas of SubSaharan Africa."Revised version of paper presented at the 1999 Chaire Quetelet Symposium in Demography, Catholic University of Louvain, Louvain-la-Neuve, Belgium. University Park, Pa: Department of Economics Working Paper, Pennsylvania State University.

Shapiro, D and T. Gebreselassie. 2008. "Falling and Stalling Fertilityin Sub-Saharan Africa." Paper presented at the International Union forthe Scientific Study of Population International Seminar on Human Fertility in Africa: Trends in the Last Decade and Prospects for Change, Cape Coast, Ghana, September 16-18, 2008.

Shastri, P. (2002) Relevance of Modernization to Population Change; Anmol Publications Pvt . Ltd

Wasao, W.S. (200I). A comparative analysis of the socioeconomic correlates offertility in Cameroon and the Central African Republic.

Webster, A. (1990). Introduction of the Sociology of Development (2nd ed.). USA: Humanities Press International Inc.

White, M.J., Muhidin, S., Stiff, C., Tagoe, E., and Knight, R. (2005) Migrationand Fertility in Coastal Ghana: An Event History Analysis. In: S.

Agyei-Mensah, J.B. Casterline, and D.K. Agyeman (eds.), Reproductive Change in Ghana: Recent Patterns and Future Prospects. Accra: University of Ghana.

White, M.J; Tagoe, E; Stiff, C; Adazu, K; and Smith, D. (2002) Urbanization and the Fertility Transition in Ghana; Brown University Providence, RI 02912

White, M.J., Mberu, B.U., and Collinson, M.A. (2008). African urbanization: Recent trends and implications. In: Martine, G., McGranahan, G., , M., and Fernández-Castilla, R. (eds.). The new global frontier. London: Earthscan.

Yamane, Taro.(1967). Statistics, An Introductory Analysis, 2nd Ed., New York: Harper and Row. 
African Population Studies Vol. 28, No. 3, 2014

Zamwangana Tungu, J. P. (2005). Migration Féminine et Fécondité à Kinshasa. Louvain-la-Neuve, Academia Bruylant. 